\title{
Soil improvement potential of weeds biomass applied as green manure in marginal land
}

\author{
ANTI DAMAYANTI HAMDANI ${ }^{1, \boldsymbol{\varphi}}$, EKA SULISTIYOWATI ${ }^{2}$, ARIFAH KHUSNURYANI ${ }^{1}$ \\ ${ }^{1}$ Program of Biology, Faculty of Science and Technology, Universitas Islam Negeri Sunan Kalijaga. Jl. Marsda Adisucipto No. 1, Sleman 55281, \\ Yogyakarta, Indonesia. Tel.: +62-274- 519739, "email: anti.h@uin-suka.ac.id \\ ${ }^{2}$ Program of Biology Education, Faculty Science and Technology, Universitas Islam Negeri Sunan Kalijaga. Sleman 55281, Yogyakarta, Indonesia
}

Manuscript received: 16 March 2017. Revision accepted: 7 April 2017.

\begin{abstract}
Hamdani AD, Sulistiyowati E, Khusnuryani A. 2017. Soil improvement potential of weeds biomass applied as green manure in marginal land. Trop Drylands 1: 12-16. Weeds have been long considered to have negative effect on crops due to competition. Yet, the presence of weeds can be used to build up organic matter and chemical contents of degraded soil. This study aimed to assess the potential of three weed species, i.e. Chromolaena odorata, Mikania micrantha, and Synedrella nodiflora, to be applied as green manure to improve soil quality in marginal land, and to assess the best form of their practical application. Two forms of weed biomass application, fresh and dried chopped, were examined in a pot experiment containing soil from degraded land in Patuk, Gunung Kidul, Yogyakarta, Indonesia, and spinach (Amaranthus tricolor L.) as the test crop. The pots were laid out in a randomized complete block design with six replications. Laboratory analysis showed that manurial properties between the weeds were statistically similar, with the average of organic $\mathrm{C}, \mathrm{N}, \mathrm{P}$ and $\mathrm{K}$ at $36.9,3.3,0.1$ and $1.6 \%$, respectively. Of the chemical contents considered, the content of all chemicals measured in experimental soil had increased, particularly the available $\mathrm{K}_{2} \mathrm{O}$ from 3.33 to the average of 46.33 ppm. The spinach growth and yield resulting from the treated soils were superior to that from untreated soils. However, there were no significant differences in the plant's response between the types of weeds. Rather, better growth and yield of spinach have resulted from soil treated with dried chopped weed biomass. Thus, weed biomass can be used to improve soil organic matter and therefore should be incorporated with soil fertility maintenance.
\end{abstract}

Keywords: Chromolaena odorata, green manure, Mikania micrantha, soil fertility, Synedrella nodiflora

\section{INTRODUCTION}

The adverse effect of intensive utilization of land for cultivation, particularly related to continued removal of nutrients from soil, in combination with highly use soildegrading agrochemicals, remains the biggest challenge in developing sustainable agriculture system. Both practices have made it difficult to maintain or enhance soil fertility, which is determined by sufficient availability of nutrients, water, air and microflora in soil to support plant growth. Such problems are more prominent on the soils classified as marginal land which have low potential soil fertility. Therefore, inexpensive systems to continually rejuvenate degraded soils are needed to support sustainable agriculture.

Technically, soil fertility can be maintained or improved by adding organic or inorganic fertilizer, or a combination of both. Nonetheless, many argue that organic amendments are more beneficial than inorganic fertilizer to develop sustainable agriculture system in the long run. Even though the application of organic fertilizer does not always fulfill the nutrient needed since its effectivity depends on many factors, such as the decomposition and nutrients release rates, the application of organic inputs can still improve soil quality in term of physical and biological elements (Hayat et al. 2010; Egbe et al. 2012).
One of the sources of organic fertilizer is plant biomass. Most of the green manures applied for cultivation are generated from biomass of the leguminous plants since they can enrich the soil content of Nitrogen that is required in large supply by most crops (Liu et al. 2008). However, the availability of legume plant biomass is limited so alternative plant sources as base materials for green manure are needed. Another group of plants that can be considered as potential plant materials is weeds. Most weeds are inexpensive, do not require much care, have rapid growth rate and are highly adaptive to various environments. Since they are available in abundance, the large amount of biomass required in their application as green manure can be fulfilled.

Weeds are often considered an enemy of the cultivation process. However, some studies demonstrated that a farmed land that has been allowed to lie idle and occupied by weeds is more productive when cultivated again than it did before because the presence of weeds can build up organic matter and chemical contents of soil. For example, Olabode et al. (2007) reported that yields from okra (Abelmoschus esculentus) in pots treated with crushed weeds tithonia (Tithonia diversifolia) were $40 \%$ higher than those without any amendments. Similarly, Jama et al. (2000) demonstrated that green manure from tithonia improved soil fertility and increase the availability of soil N, P and K. Application of Erigeron annuus (L.) improve 
soil $\mathrm{pH}$ and nutrient concentrations in the acid soils of southern China (Liu et al. 2008). Likewise, Patel (2012) also mentioned the potential utilization of weed Eichhornia crassipes as materials for green manure. Therefore, when weeds are harvested it can be applied as green manure while on the other hand reducing their competition with the main crops with the expected results of better growth and yield of the cultivated crops.

The highly abundance of weeds should be considered as an advantage to help building up the impoverished soils, especially to solve the problem of soil fertility in marginal land. However, not every weed might be potential as green manure base material. The suitability of plant material for soil amendment depends on the occurrence of high $\mathrm{N}, \mathrm{P}$ and $\mathrm{K}$ concentrations in plant tissues (Gachengo et al. 1999; Tomar et al. 2012). For example, most green manure is plant biomass generated from legume family because they contain high level of $\mathrm{N}$ in their tissues. In addition, the quality of green manure is also determined by the relative proportions of lignin, the high rate of decomposition and nutrient release (Olabode et al. 2007). Tithonia, for instance, was considered as a better source of plant materials/biomass for green manure than Senna spectabilis (senna) because the release rate of $\mathrm{N}$ and $\mathrm{P}$ from tithonia is higher than from senna (Gachengo et al. 1999).

In this experiment, we assessed the extent to which organic matters or biomass of three species recognized as weeds, i.e. Chromolaena odorata, Mikania micrantha, and Synedrella nodiflora, can be used to improve the fertility of experimental soil from marginal land in Patuk, Gunung Kidul, Yogyakarta, Indonesia. These weeds species were selected because of their availability in a large supply, had high biomass and were expected to decompose easily due to their low lignin contents. Also, two forms of applications, i.e. fresh and dried chopped weeds, were tested to determine the best mode of their practical application. The application was without fermentation based on the previous study results (Olabode et al. 2007) that soils treated with crushed tithonia showed higher $\mathrm{N}$ concentration over the soils treated with fermented tithonia. This could be another strong point since unfermented process would simplify the application of green manures.

\section{MATERIALS AND METHODS}

\section{Soil sampling and analysis}

The soil samples were collected in September 2015 from the $0-20 \mathrm{~cm}$ horizon of all plots in Patuk, Gunung Kidul, Yogyakarta. Physical and chemical characteristics of the soils were determined according to standard methods in BPTP Yogyakarta. Physical analysis included determination of soil texture (sand, dust, clay) using hydrometer method. As for chemical characteristics, the total $\mathrm{N}$ was determined by Kjeldahl method, available $\mathrm{P}_{2} \mathrm{O}_{5}$ was determined by Olsen method, available $\mathrm{K}_{2} \mathrm{O}$ was determined by water-soluble extraction, potential $\mathrm{P}_{2} \mathrm{O}_{5}$ and $\mathrm{K}_{2} \mathrm{O}$ were determined by extraction using $25 \% \mathrm{HCl}$, and organic carbon was determined by Walkley and Black method.

\section{Plant sampling and analysis}

Three species of weeds used in this study were Chromolaena odorata, Mikania micrantha, and Synedrella nodiflora. The weed samples were collected randomly from several farming areas in Sleman, Yogyakarta and then pooled. The plants were harvested at ground level, but only the leaves were used as green manures. Chemical analysis of the weed samples was done according to standard methods in BPTP Yogyakarta. The total $\mathrm{N}$ was determined by Kjeldahl method, $\mathrm{P}$ was determined by spectrometer, $\mathrm{K}$ was determined by AAS, and organic carbon was determined by Walkley and Black method.

\section{Pot experiment}

Two treatments, corresponding to two forms of weed preparations (i.e. fresh and dried chopped) for each type of weed, were compared to the control groups of pots without any soil amendments (negative control) and pots supplemented with inorganic fertilizer. Those were fitted into a randomized complete block experiment. There were 24 pots such that three pots represented each group with six replications. Each of the pots was filled with soil taken from the experimental area in Patuk, Gunung Kidul, Yogyakarta, and the roughly chopped leaves (fresh weight) with a ratio of 10:1. The pots were then incubated for two weeks before planting and during the time were watered every morning and afternoon. After two weeks, samples from soils treated with chopped weeds biomass were collected for analysis of available nutrient status in BPTP Yogyakarta.

For the fresh chopped treatment, the chopped leaves were directly mixed thoroughly with the soil, while for the dried chopped treatment; the chopped leaves were mixed with the soil after being dried in the sun for two days. Nothing was added to the soil assigned as the negative control pots while the positive control pots were supplemented with NPK fertilizer $\left(60 \mathrm{~kg} \mathrm{ha}^{-1}\right)$ according to the users' guide.

The spinach seeds were sowed in advance for two weeks, before planting in the pots. Each pot was watered as needed as well as the mulching. Data collected included plant height, number of leaves, root length, and fresh weight.

\section{Data analysis}

The plant and soil data were analyzed statistically using the analysis of variance (ANOVA) using IBM SPSS Statistics 21. The difference of treatment result was assessed using Duncan test for separating the mean of treatments at $5 \%$.

\section{RESULTS AND DISCUSSION}

Physical and chemical characteristics of the soil used in this study were presented in Table 1 . The analysis on soil physical properties showed that the soil was dominated by clay content, which reached up to $47 \%$, followed by sand content of as much as $27 \%$ and $25.67 \%$ of dust, hence the experimental soil was categorized as clay soil. The N, P, K, 
and organic carbon of soil were generally very low, implying that the level of soil fertility was also very low.

Meanwhile, the tissue nutrient concentrations of Chromolaena odorata, Mikania micrantha, and Synedrella nodiflora used in this study were presented in Table 2. Overall, the $\mathrm{N}, \mathrm{P}, \mathrm{K}$ and organic $\mathrm{C}$ tissue contents were statistically similar. The highest organic $\mathrm{C}$ was found in $C$. odorata, respectively 8.26 and $7.42 \%$ better than $M$. micrantha and $S$. nodiflora. Likewise, $C$. odorata was also 6.58 and $6.92 \%$, respectively better than $M$. micrantha and $S$. nodiflora in N tissue contents. Meanwhile, M. micrantha was better than $C$. odorata by $60 \% \mathrm{P}$ and $77.78 \% \mathrm{~K}$, also 82.61 and $27.27 \%$ better in $\mathrm{K}$ tissue contents than in $C$. odorata and $S$. nodiflora, consecutively. With regard to the same ratio of $\mathrm{C} / \mathrm{N}$ in those weeds, the succulent level of $C$. odorata, M. micrantha and S. nodiflora were the same, indicating a similar rate of decomposition process. Therefore, $C$. odorata, $M$. micrantha and $S$. nodiflora could have similar manurial potential.

The occurrence of $\mathrm{N}, \mathrm{P}, \mathrm{K}$ and organic $\mathrm{C}$ concentrations in all selected weeds were considered high. When compared to the reported values of other sources of green manures, the nutrient contents of $C$. odorata, $M$. micrantha and $S$. nodiflora were comparable to tithonia (Tithonia diversifolia), the weed that considered as a high-quality organic source for green manure, which contained $31.76 \%$ organic C, $4.46 \% \mathrm{~N}, 0.61 \mathrm{P}$ and $3.75 \% \mathrm{~K}$ (Hafifah et al. 2016). However, the nutrient status of plants varied with soil characteristics, geographical conditions and ecological status of the plants. The occurrence of very high nutrient concentration in plant materials can be obtained from fertile soil. For example, $\mathrm{N}$ concentration in $C$. odorata samples used in this study was higher than that found in the same species collected from the savanna of Nigeria (3.4 as opposed to 1.76, respectively) (Olabode et al. 2007). Therefore, the effective use of plant materials as green manure should consider the conditions of plant source location, coupled with the availability of plants and the level of nutrient deficiency of treated soil.

The chemical characteristics of soil after incubated with the chopped weeds for two weeks (Table 3) showed the increasing level of $\mathrm{N}, \mathrm{P}, \mathrm{K}$ and organic $\mathrm{C}$, particularly on available $\mathrm{K}_{2} \mathrm{O}$ that drastically increase from 3.33 ppm to an average of $46.33 \mathrm{ppm}$. Overall, the level of soil fertility had increased from very low to low with the addition of chopped weeds.

From the three plant species used in this research, $C$. odorata has the highest potential to increase soil chemical properties. Previous research regarding $C$. odorata showed a similar trend. For example, Nawaz and George (2004) reported that organic compost of $C$. odorata was able to increase crop biomass, and interestingly, this compost had similar effect to the use of cattle manure. When it was used as green manure, $C$. odorata was reported to increase NPK uptake and nutrient efficiency in paddy cultivation (Murthy et al. 2010).

Mikania micrantha showed allelopathic properties when it was used as green manure as it has been reported to have allelopathic effect on some weeds in crop fields (Weng 1964). Ullah et al. (2014) administered extract of $M$. micrantha to Fymbristylis miliacea weed and reported that it significantly lower Fymbristylis population. This gives less preferable effect as green manure compared to the other two plant species used in this experiment.

Murthy et al. (2010) asserted that the use of weeds as organic manure could increase the quality of soil chemical properties. The data shown in Table 3 confirmed that statement.

In terms of $\mathrm{C}$ and $\mathrm{N}$ properties, it seems that dried chopped $C$. odorata gave slightly better $\mathrm{C}$ and $\mathrm{N}$ improvement. This result is almost in close conformity with the findings of the usage of $C$. odorata for increasing the yield of rice (Paraye 2002). This manurial practice could help in enhancing biochemical activity of microorganisms living in sandy loam and sandy clay soils (Paraye 2002), exactly similar to the type of soil used in this research. In terms of amendment of available $\mathrm{P}_{2} \mathrm{O}_{5}$, and $\mathrm{K}_{2} \mathrm{O}$, as well as potential $\mathrm{P}_{2} \mathrm{O}_{5}$ and $\mathrm{K}_{2} \mathrm{O}$, all weeds used, could improve soil chemical properties. Sandy-clay soil is typically low in available phosphorous, hence in traditional farming practice, farmers tend to supply the need of $\mathrm{P}$ from inorganic sources. However, in alkaline soil, like clay, $\mathrm{P}$ reacts with $\mathrm{Fe}$ and $\mathrm{Al}$ and creates insoluble $\mathrm{P}$. The use of green manure could reduce this risk, because it increases availability of $\mathrm{P}$ and reduces soil capacity to react with $\mathrm{P}$, and thus $\mathrm{P}$ is more readily available for plants (Mweta et al. 2007).

Of the plant response considered (Figure 3, Table 4), plant growth and yields from soil supplemented with chopped weeds were superior to that from soil without the addition of fertilizers, for all the measured parameters, and were parallel with those treated with NPK fertilizer. And among the treated soil, better plant growth and yields were observed from soil added with dried chopped weeds than fresh weeds, but not significantly different according to the types of weeds used.

Table 1. The initial physical and chemical properties of soil used for the study

\begin{tabular}{lr}
\hline Property & Value \\
\hline $\mathrm{pH}$ & 7.00 \\
Particle Density $\left(\mathrm{g} \mathrm{cc}^{-1}\right)$ & 2.61 \\
Organic Carbon $(\%)$ & 0.65 \\
Total Nitrogen (\%) & 0.08 \\
C/N Ratio & $8: 1$ \\
Available $\mathrm{P}_{2} \mathrm{O}_{5}-\mathrm{Olsen}(\mathrm{ppm})$ & 7.33 \\
Potential $\mathrm{P}_{2} \mathrm{O}_{5}-25 \% \mathrm{HCl}\left(\mathrm{mg} 100 \mathrm{~g}^{-1}\right)$ & 55.33 \\
Available $\mathrm{K}_{2} \mathrm{O}-\mathrm{Olsen}(\mathrm{ppm})$ & 3.33 \\
Potential $\mathrm{K}_{2} \mathrm{O}-25 \% \mathrm{HCl}\left(\mathrm{mg} 100 \mathrm{~g}^{-1}\right)$ & 5.33 \\
Sand $(\%)$ & 27.00 \\
Silt $(\%)$ & 25.67 \\
Clay $(\%)$ & 47.00 \\
\hline
\end{tabular}

Table 2. Chemical properties of Chromolaena odorata, Mikania micrantha, and Synedrella nodiflora.

\begin{tabular}{|c|c|c|c|c|c|}
\hline \multirow{2}{*}{ Weed species } & \multicolumn{5}{|c|}{ Manurial properties (\%) } \\
\hline & Org. ( & $\mathbf{N}$ & $\mathbf{P}$ & $\mathbf{K}$ & $\mathrm{C} / \mathrm{N}$ \\
\hline Mikania micrantha & 35.81 & 3.19 & 0.16 & 2.1 & $11: 1$ \\
\hline Chromolaena odorata & 38.77 & 3.4 & 0.09 & 1.15 & $11: 1$ \\
\hline Synedrella nodiflora & 36.09 & 3.18 & 0.1 & 1.65 & $11: 1$ \\
\hline
\end{tabular}


Table 3. The effect of weeds application on chemicals soil characteristics

\begin{tabular}{|c|c|c|c|c|c|c|}
\hline Form of weed biomass & $\begin{array}{c}\text { Organic C } \\
(\%)\end{array}$ & $\begin{array}{c}\text { Total N } \\
(\%)\end{array}$ & $\begin{array}{c}\text { Available } \mathrm{P}_{2} \mathrm{O}_{5} \\
(\mathrm{ppm})\end{array}$ & $\begin{array}{c}\text { Available } \mathrm{K}_{2} \mathrm{O} \\
(\mathrm{ppm})\end{array}$ & $\begin{array}{c}\text { Potential } \mathrm{P}_{2} \mathrm{O}_{5} \\
\left(\mathrm{mg} 100 \mathrm{~g}^{-1}\right)\end{array}$ & $\begin{array}{c}\text { Potential } \mathrm{K}_{2} \mathrm{O} \\
\left(\mathrm{mg} 100 \mathrm{~g}^{-}\right)\end{array}$ \\
\hline Negative control & $0.65^{\mathrm{a}}$ & $0.07^{\mathrm{a}}$ & $7.33^{\mathrm{a}}$ & $3.33^{\mathrm{a}}$ & $55.33^{\mathrm{a}}$ & $5.33^{\mathrm{a}}$ \\
\hline $\begin{array}{l}\text { Mikania micrantha } \\
\text { Fresh chopped } \\
\text { Dried chopped }\end{array}$ & $\begin{array}{l}0.89^{\mathrm{ab}} \\
0.97^{\mathrm{ab}}\end{array}$ & $\begin{array}{l}0.10^{\mathrm{b}} \\
0.11^{\mathrm{bc}}\end{array}$ & $\begin{array}{c}9.33^{\mathrm{a}} \\
11.67^{\mathrm{a}}\end{array}$ & $\begin{array}{l}48.67^{b} \\
43.33^{b}\end{array}$ & $\begin{array}{l}75.67^{\mathrm{a}} \\
63.67^{\mathrm{a}}\end{array}$ & $\begin{array}{l}12.00^{\mathrm{bc}} \\
9.67^{\mathrm{b}}\end{array}$ \\
\hline $\begin{array}{l}\text { Chromolaena odorata } \\
\text { Fresh chopped } \\
\text { Dried chopped }\end{array}$ & $\begin{array}{l}1.06^{\mathrm{ab}} \\
1.27^{\mathrm{b}}\end{array}$ & $\begin{array}{l}0.12^{\mathrm{c}} \\
0.13^{\mathrm{c}}\end{array}$ & $\begin{array}{c}9.00^{\mathrm{a}} \\
12.00^{\mathrm{a}}\end{array}$ & $\begin{array}{l}49.33^{\mathrm{b}} \\
41.00^{\mathrm{b}}\end{array}$ & $\begin{array}{l}69.67^{\mathrm{a}} \\
61.33^{\mathrm{a}}\end{array}$ & $\begin{array}{l}9.00^{\mathrm{b}} \\
9.67^{\mathrm{b}}\end{array}$ \\
\hline $\begin{array}{l}\text { Synedrella nodiflora } \\
\text { Fresh chopped } \\
\text { Dried chopped }\end{array}$ & $\begin{array}{l}1.00^{\mathrm{ab}} \\
1.09^{\mathrm{ab}}\end{array}$ & $\begin{array}{l}0.11^{\mathrm{bc}} \\
0.11^{\mathrm{bc}}\end{array}$ & $\begin{array}{c}8.67^{\mathrm{a}} \\
16.00^{\mathrm{a}}\end{array}$ & $\begin{array}{l}47.67^{\mathrm{b}} \\
48.00^{\mathrm{b}}\end{array}$ & $\begin{array}{l}60.67^{\mathrm{a}} \\
58.00^{\mathrm{a}}\end{array}$ & $\begin{array}{l}10.00^{\mathrm{bc}} \\
13.00^{\mathrm{c}}\end{array}$ \\
\hline
\end{tabular}

Note: Means along the column with the same superscript are not significantly different by Duncan test $(\alpha=0.05)$

It was not surprising since the manurial properties of $C$. odorata, M. micrantha and S. nodiflora were similar. However, better results observed from soil treated with dried chopped weeds than those from fresh chopped were inconsistent with the finding of Olabode et al. (2007). This could be caused by different modes of application. Olabode et al. (2007) applied crushed fresh and ground dried to the soil while in this study we used the roughly chopped weeds for practical applications. When incorporated with the experimental soil, the dried chopped weeds were more easily broken into smaller pieces, hence increasing the surface area for decomposition and fastening the process, as opposed to the fresh ones. Therefore, the soil nutrient supplies required for plant growth were more readily available in the soil incorporated with dried chopped weeds.

We concluded from the present study results that the weeds Chromolaena odorata, Mikania micrantha, and Synedrella nodiflora have the potential to be used as green manures to improve soil fertility. According to this study, dried chopped weeds were more preferable to without drying process. This application should, therefore, be incorporated with weeds management for more efficient ecosystems services.
Table 4. The effect of weed biomass application on spinach growth and yields.

\begin{tabular}{|c|c|c|c|c|}
\hline $\begin{array}{l}\text { Form of weed } \\
\text { biomass }\end{array}$ & $\begin{array}{l}\text { Plant } \\
\text { height } \\
\text { (cm) }\end{array}$ & $\begin{array}{l}\text { Root } \\
\text { length } \\
\text { (cm) }\end{array}$ & $\begin{array}{l}\text { Numbers } \\
\text { of leaves }\end{array}$ & $\begin{array}{l}\text { Fresh } \\
\text { weight } \\
\text { (g) }\end{array}$ \\
\hline \multicolumn{5}{|l|}{ Negative control } \\
\hline & $5.83^{\mathrm{a}}$ & $4.00^{\mathrm{a}}$ & $2.33^{\mathrm{a}}$ & $0.19^{\mathrm{a}}$ \\
\hline \multicolumn{5}{|c|}{ Mikania micrantha } \\
\hline Fresh chopped & $31.12^{\mathrm{b}}$ & $8.82^{\mathrm{a}}$ & $10.00^{\mathrm{ab}}$ & $16.27^{\mathrm{b}}$ \\
\hline Dried chopped & $47.20^{\mathrm{d}}$ & $20.60^{\mathrm{b}}$ & $30.20^{c}$ & $22.77^{\mathrm{b}}$ \\
\hline \multicolumn{5}{|c|}{ Chromolaena odorata } \\
\hline Fresh chopped & $40.78^{\mathrm{bcd}}$ & $8.15^{\mathrm{a}}$ & $14.50^{\mathrm{ab}}$ & $27.71^{\mathrm{b}}$ \\
\hline Dried chopped & $48.60^{\mathrm{d}}$ & $16.80^{\mathrm{b}}$ & $29.40^{c}$ & $30.58^{b}$ \\
\hline \multicolumn{5}{|c|}{ Synedrella nodiflora } \\
\hline Fresh chopped & $33.80^{\mathrm{bc}}$ & $8.33^{\mathrm{a}}$ & $12.00^{\mathrm{ab}}$ & $24.21^{\mathrm{b}}$ \\
\hline Dried chopped & $43.80^{\mathrm{bcd}}$ & $33.80^{c}$ & $28.20^{\mathrm{c}}$ & $23.63^{\mathrm{b}}$ \\
\hline
\end{tabular}

Positive control

$46.00^{\text {cd }} \quad 21.67^{\mathrm{b}} \quad 18.00^{\mathrm{bc}} \quad 17.54^{\mathrm{b}}$

Note: Means along the column with the same superscript are not significantly different by Duncan test $(\alpha=0.05)$.

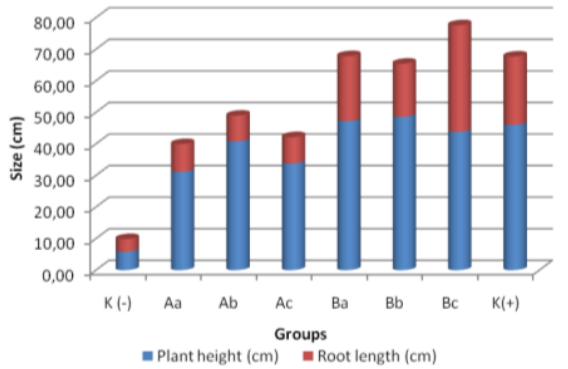

A

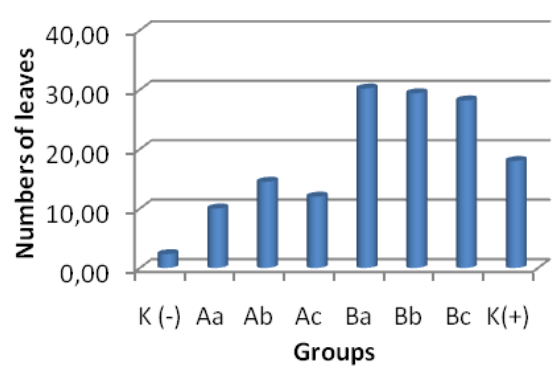

B

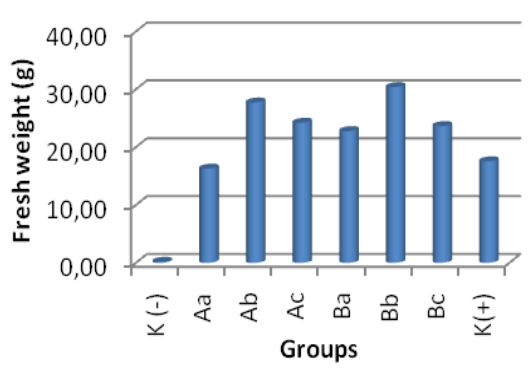

C

Figure 3. Plant growth and yields response of spinach planted in soil treated with chopped weeds as opposed to soil without any amendments (negative control) and soil supplemented with NPK fertilizer (positive control). The measured parameters included plant height and root length (A), the number of leaves (B), and fresh weight (C) at the harvest time of 40 days after planting. A= fresh chopped weeds treatment group; $\mathrm{B}=$ dried chopped weeds treatment group; $\mathrm{a}=$ Mikania micrantha; $\mathrm{b}=$ Chromolaena odorata $; \mathrm{c}=$ Synedrella nodiflora 


\section{ACKNOWLEDGEMENTS}

We would like to thank the Ministry of Religious Affairs of Republic Indonesia for the financial support of this work through Research Grant 2015.

\section{REFERENCES}

Egbe EA, Fonge BA, Mokak SE, Besong M, Fongod AN. 2012. The effects of green manure and NPK fertilizer on the growth and yield of maize (Zea mays L) in the Mount Cameroon region. Agric Biol J North Amer 3 (3): 82-92. DOI : 10.5251/abjna.2012.3.3.82.92

Gachengo CN, Palm CA, Jama B, Othieno C. 1999. Tithonia and senna green manures and inorganic fertilizers as phosphorus sources for maize in Western Kenya. Agrofor Syst 44: 21-36. DOI: 10.1023/A:1006123404071

Hafifah, Sudiarso, Maghfoer MD, Prasetya B. 2016. The potential of Tithonia diversifolia green manure for improving soil quality for cauliflower (Brassica oleracea var botrytis L.). J Degrad Mining Lands Manag 3 (2): 499-506. DOI: 10.15243/jdmlm.2016.032.499

Hayat R, Ali S, Amara U, Khalid R, Ahmed I. 2010. Soil beneficial bacteria and their role in plant growth promotion: A review. Ann Microbiol 60 (4): 579-598. DOI: 10.1007/s13213-010-0117-1

Jama B, Palm CA, Buresh RJ, Niang A, Gachengo C, Nziguheb C, Amadal B. 2000. Tithonia diversifolia as a green manure for soil fertility improvement in western Kenya: A review. Agrofor Syst 49: 201-221. DOI: 10.1023/A:1006339025728

Liu J, Peng S, Faivre-Vuillin B, Xu Z, Zhang D, Zhou G. 2008. Erigeron annuus (L.) Pers. as a green manure for ameliorating soil exposed to acid rain in Southern China. J Soils Sediments 8 (6): 452-460. DOI :10.1007/s11368-008-0041-1.

Murthy RK, Raveendra HR, Reddy MTB. 2010. Effect of Chromolaena and Parthenium as green manure and their compost on yield, uptake and nutrient use efficiency on typic paleustalf. Eur Biol Sci 4 (1): 41 45. www.ejarr.com/Volumes/Vol4/EJBS_4_07.pdf.

Mweta DE, Akinnifesi FK, Saka JDK, Makumba W, Chokotho N. 2007. Green manure from prunings and mineral fertilizer affect phosphorus adsorption and uptake by maize crop in a gliricidia-maize intercropping. Sci Res Essay 2 (10): 446-453.

Nawaz M, Sansamma G. 2004. Eupatorium [Chromolaena odorata (L.) King and Robinson] biomass as a source of organic manure in okra cultivation. J Trop Agric 42 (1-2): 33-34.

Olabode OS, Sola O, Akanbi WB, Adesina GO, Babajide PA. 2007. Evaluation of Tithonia diversifolia (Hemsl.) a gray for soil improvement. World J Agric Sci 3 (4): 503-507.

Paraye PM. 2002. Studies on Green Manuring of Eupatorium (Chromolaena odorata L.). in Aromatic Rice (Oryza sativa). [Thesis]. University of Agricultural Sciences, Dharwad, India

Patel S. 2012. Threats, management and envisaged utilizations of aquatic weed Eichhornia crassipes: An overview. Rev Environ Sci Biotechnol 11 (3): 249-259. DOI: 10.1007/s11157-012-9289-4

Ullah MJ, Rahman J, Yeasmin M, Fatima K, Quamruzzaman M. 2014. Allelopathic effect of mikania (Mikania micrantha) in Kharif season to control Fymbristylis miliacea weeds. J Expt Biosci 5 (2): 79-86. 